\title{
TARI TOPENG IRENG BANDUNGREJO, NGABLAK, MAGELANG
}

\author{
Budi Setyastuti \\ Program Pascasarjana \\ Institut Seni Indonesia Surakarta \\ JI. Ki Hadjar Dewantara No. 19 Kentingan, Jebres, Surakarta, 57126
}

\begin{abstract}
ABSTRAK
Penelitian bertujuan menggali bentuk dan fungsi sosial seni dalam adat budaya Bandungrejo. Penelitian menggunakan pendekatan kualitatif yang bersifat deskriptif. Metode pengumpulan data yang digunakan meliputi observasi, wawancara, dokumentasi dan studi pustaka. Teknik analisis data menggunakan deskriptif interpretatif. Penarikan simpulan melalui verifikasi, yang aktifitas terdiri dari reduksi data, sajian data dan laporan hasil penelitian. Hasil yang dicapai Topeng Ireng memiliki makna penting bagi kehidupan masyarakat Bandungrejo. Banyak fungsi yang berperan aktif kesenian rakyat Topeng Ireng bagi masyarakat di antaranya fungsi estetis, hiburan, perlambang, pengesahan lembaga sosial dan ritus kehidupan, pengintegrasian masyarakat, ritual, dan pendidikan. Faktor-faktor pendukung dan penghambat baik secara intern dan ekstern meliputi kondisi dan situasi masyarakat setempat dan kehadiran masyarakat desa sekitar.
\end{abstract}

Kata kunci: topeng ireng, upacara adat, fungsi, faktor pendukung dan penghambat.

\begin{abstract}
The research aims to explore the form and function of social arts in Bandungrejo cultural customs. The Research uses qualitative approaches that are descriptive. The method of collecting data used includes observations, interviews, documentation and literature review. The data analysis uses descriptive and interpretive. Conclusion withdrawal through verification, the activity consists of data reduction, data presentation and research report results. The results achieved by Topeng Ireng have an important meaning for the life of Bandungrejo. Many functions that play an active role in the folk art of Topeng Ireng are among others aesthetic functions, entertainment, symbolism, ratification of social institutions and rites of life, integration of society, rituals, and education. Supporting and inhibiting factors both internally and externally include the conditions and situation of the local community and the presence of the surrounding village community.
\end{abstract}

Keywords: ireng mask, traditional ceremony, function, supporting and inhibiting factors.

\section{A. Pengantar}

Upacara adat bersih desa merupakan budaya masyarakat Jawa Tengah pada umumnya. Di dalam upacara adat bersih desa, sebagian besar masyarakat percaya akan mendatangkan keselamatan, kedamaian, kebahagiaan dan keberhasilan dalam pertanian. Berbagai bentuk seni ditampilkan yang seluruh paraganya berasal dari masyarakat setempat. Kehadiran penonton dari desa lain yang masih kerabat dan masyarakat umum menambah gairah terselenggaranya bersih desa. Topeng Ireng merupakan salah satu tari yang digunakan untuk pelengkap upacara adat bersih desa.

Bentuk Tari Topeng Ireng diilhami oleh tari prajuritan. Formasi penari berbentuk barisan, penari berjalan sepanjang jalan. Topeng Ireng berjenis tari kelompok yang didukung oleh 18 (delapan belas) orang penari laki-laki. Dalam perkembangannya di
Bandungrejo Topeng Ireng juga ditarikan oleh dua orang penari wanita. Para penari mengenakan tata rias dan tata busana yang hampir sama, perbedaan terletak pada penggunaan warna pada aksen-aksen tertentu. Topeng Ireng tidak bertema ceritera, durasi pementasan menurut situasi dan keperluannya.

Bagi masyarakat Bandungrejo upacara bersih desa merupakan adat budaya yang telah dilakukan secara turun-temurun sejak dahulu kala. Dalam upacara selalu disertai dengan kegiatan gotong-royong membersihkan lingkungan, gotong-royong selamatan, dan pentas seni. Berbagai sesaji, doa menurut ajaran Jawa dan Islam dipanjatkan agar terkabul seluruh citacita warga desa. Semua potensi seni dan kemampuan warga desa disumbangkan secara suka rela pada waktu bersih desa. Beberapa faktor pendukung dan penghambat terselenggaranya upacara bersih desa dengan pesta seni selalu muncul, merupakan dinamika kehidupan masyarakat desa. Upacara adat 
bersih desa dengan Topeng Ireng sebagai sarana upacara telah terselenggara sejak satu dasawarsa terakhir. Diperlukan penelitian yang seksama untuk mengetahui fungsi Topeng Ireng yang berkaitan dengan upacara adat bersih desa Bandungrejo. Permasalahan yang diangkat adalah bentuk dan fungsi tari Topeng Ireng sebagai sarana upacara adat bersih desa Bandungrejo, Kecamatan Ngablak, Kabupaten Magelang serta faktor pendukung dan penghambat tari Topeng Ireng yang digunakan sebagai upacara adat bersih desa

Penelitian ini termasuk jenis penelitian kualitatif dengan sumber data yang bersifat naratif. Teknik analisis data menggunakan metode deskriptif interpretatif. Data diperoleh dari observasi, wawancara, dan dokumentasi terhadap informan yang sudah terseleksi. Informan dipilih secara berantai untuk lebih memperdalam data. Pendekatan yang digunakan adalah antropologi sosial seni dengan melibatkan semua komponen masyarakat, tindakan bersifat kreatif dan inovatif.

Pengambilan data diperoleh melalui: observasi atau pengamatan terhadap obyek penelitian. Observasi dilakukan dengan dua cara yaitu observasi langsung dan tidak langsung. Observasi langsung peneliti mengamati obyek berupa pertunjukan Topeng Ireng yang sedang dipentaskan dalam rangka upacara adat bersih desa. Berbagai aspek yang menjadi sasaran misalnya aspek hiburan, estetis, perlambang, pengesahan lembaga sosial, ritus kehidupan, pengintegrasian masyarakat, dan ritual. Observasi tidak langsung dilakukan melalui hasil rekaman pada saat penelitian maupun yang sudah direkam pada waktu yang lalu, tersimpan sebagai koleksi pustaka di Dinas Pariwisata Magelang.

Wawancara, dilakukan dengan dua cara yaitu wawancara bebas dan terprogram. Wawancara bebas dilakukan terhadap beberapa informan dan nara sumber untuk memperoleh data yang sifatnya umum meliputi riwayat pertunjukan, kondisi masyarakat, upacara adat desa.

Wawancara terprogram dilakukan untuk menggali data yang benar-benar diperlukan dalam penelitian. Untuk wawancara terprogram peneliti telah menyiapkan sejumlah daftar pertanyaan yang meliputi struktur dramatik pementasan, fungsi upacara adat bagi masyarakat, fungsi seni bagi masyarakat, faktor pendorong dan penghambat, lembaga penyelenggara, berbagai hambatan dan cara melakukan penyelesaian. Pada saat wawancara berlangsung juga dilakukan pencatatan serta rekaman audio visual. Maksud rekaman agar setelahwawancara tidak ada data yang terlewatkan.
Studi pustaka, pengumpulan data lewat penelaahan kepustakaan merupakan studi awal guna mendapatkan informasi secara tertulis dengan melakukan pengumpulan dan mempelajari beberapa referensi. Referensi diperoleh dari data-data tertulis dan tercetak berupa buku, foto, artikel, manuskrip, majalah, dan surat kabar yang berhubungan langsung dan tidak langsung dengan objek penelitian.

Untuk menjaga validitas data penelitian yang dikumpulkan digunakan teknik triangulasi sumber, triangulasi teori, triangulasi metode. Triangulasi sumber data artinya, pengumpulan data melalui narasumber dari tiap pertunjukan Topeng Ireng yang hidup di wilayah penelitian. Triangulasi teori, artinya mengumpulkan data sejenis dengan menggunakan teori yang berbeda dalam teori tentang seni dan ritual. Triangulasi metode, artinya mengumpulkan data melalui berbagai metode seperti metode wawancara, observasi, analisis bentuk pertunjukan, dan sebagainya.

Penelitian menggunakan teknik analisis deskrriptif interpretatif seperti lazim yang digunakan pada kajian budaya ilmu-ilmu sosial humaniora, terdiri atas tiga komponen analisis, yaitu reduksi data, sajian data, dan penarikan simpulan atau verifikasi, yang aktifitas ketiganya dilakukan dalam bentuk interaktif dengan proses pengumpulan data sebagai proses siklus. Dalam model peneliti tetap bergerak di antara ketiga komponen selama proses pengumpulan data penelitian dilakukan.

\section{B. Tata Cara Upacara Adat Bersih Desa Bandungrejo, Ngablak, Magelang.}

\section{Upacara Adat Bersih Desa Bandungrejo}

Upacara adat bersih desa yang berlangsung di Bandungrejo merupakan tradisi masyarakat yang dilaksanakan setiap tahun jatuh pada bulan Sapar dalam penanggalan Jawa. Upacara adat dilaksanakan oleh warga masyarakat, didukung oleh masyarakat desa lain baik berupa dana maupun kegiatan. Upacara adat bersih desa bagi masyarakat Bandungrejo merupakan kegiatan yang dianggap penting demi kelangsungan hidup bermasyarakat. Sistem kehidupan masyarakat sehari-hari dilandasi oleh ajaran agama dan unsur kepercayaan yang merupakan adat kebiasaan lama.

Pelaksanaan upacara adat bersih desa Bandungrejo adalah salah satu wahana untuk mendekatkan diri kepada Tuhan Pencipta Alam. Perilaku manusia dapat dilihat secara tindakan simbolis, seperti adanya ujub yang diamini oleh warga 


\section{GEEAR Jumal sai isulya}

doa maupun sesaji. Ujub adalah ucapan rois desa tentang maksud dan tujuan diselenggarakannya selamatan. Doa merupakan ungkapan melalui katakata yang berisikan tentang permohonan dan ucapan syukur pada Tuhan. Sesaji berupa makanan maupun bahan mentah diperuntukkan dewa atau dhanyang leluhur serta Dewi Sri. Antara kepercayaan terhadap sang pencipta, dhanyang leluhur desa, Dewi Sri dan kekuatan alam menjadi sistem kepercayaan yang membaur menjadi satu dipercaya dan dijadikan tuntunan hidup masyarakat Bandungrejo sebagai langkah untuk mencapai suatu kesejahteraan hidup serta keselamatan jiwa.

Menurut Taryono pelaksanaan bersih desa seperti sekarang merupakan warisan leluhur apa yang telah dilakukan oleh orang-orang tua terdahulu (Taryono, wawancara 8 Nopember 2014). Upacara bersih desa sebagai upacara adat kebiasaan di Bandungrejo tidak diketahui secara pasti kapan pertama kali terselenggara. Penyelenggaraan upacara adat memiliki maksud sebagai ungkapan rasa syukur kepada sang pencipta atas berkah yang diberikan dengan melimpah melalui hasil bumi (Wargo, wawancara 8 Nopember 2014).

Masyarakat Desa Bandungrejo merasa kehidupan dijaga dan dilindungi oleh roh-roh para leluhur dari berbagai marabahaya. Oleh sebab itu warga merasa pada waktu tertentu perlu memperhatikan makhluk halus dengan memberikan sajen. Masyarakat menyajikannya dengan mengadakan upacara bersih desa (merti desa) yang dilaksanakan pada bulan Sapar, waktu pelaksanaan mencari hari yang dianggap baik oleh masyarakat contoh salah satunya Rebu Kliwon. Pada hari-hari tertentu masyarakat juga masih membuat sajen kecil untuk roh para leluhurnya, seperti pada malam Jum'at Kliwon, dan Selasa Kliwon.

Masyarakat Bandungrejo mempunyai kepercayaan dhanyang adalah roh atau makhluk halus menempati alam semesta di sekeliling tempat tinggal kediamannya, misalnya di dalam sumber mata air atau sendhang, di perempatan dan ditempat-tempat yang dianggap angker. Bagi masyarakat membuat rasa senang para dhanyang, agar tidak marah sehingga tidak mengganggu, sebaliknya akan membantu keinginan masyarakat. Sebagian masyarakat Bandungrejo setiap tahunnya memberi imbalan yaitu dengan mengadakan selamatan desa yang disertai adanya sesajen untuk roh dan menampilkan pertunjukan kesenian. Geertz dhanyang adalah nama lain dari demit atau sebagai roh tokohtokoh sejarah yang sudah meninggal, pendiri desa tempat mereka tinggal/orang pertama yang membabat hutan dan pundhen adalah sebagai tempat tinggal menetap dhanyang. Dhanyang dianggap menerima permohonan orang untuk minta tolong dan sebagai imbalannya menerima persembahan selamatan. Dhanyang tidak menyakiti masyarakat melainkan membantu maksud warga masyarakat serta melindungi (1981:32).

\section{Tatacara Bersih Desa}

\section{a. Persiapan Upacara}

Upacara adat bersih desa pada bulan Sapar atau dikenal dengan Saparan merupakan kegiatan bersama yang didukung oleh semua warga masyarakat. Dalam pelaksanaannya sebagai persiapan disusun kepanitiaan. Panitia penyelenggara mengadakan musyawarah untuk menentukan hari dan tanggal pelaksanaan yaitu jatuh pada hari Rabu Kliwon, tempat pelaksanaan upacara adat bersih desa dan penentuan dana yang diperlukan. Oleh karena upacara adat bersih desa merupakan peristiwa yang melibatkan semua masyarakat Bandungrejo, maka tempat yang dipilih untuk upacara adalah di tempat salah satu warga yang memiliki halaman rumah yang lebar (Sugianto Wawancara, 7 Juli 2014).

Pada pelaksanaan upacara adat disediakan sesaji atau sajen yang lebih di kenal dengan Sesaji Dewa Rimba. Sajen yang ditata rapi dipersembahkan kepada dhanyang desa. Sajen dimantrai dari sesepuh agar menimbulkan kepuasan warga desa maupun dhanyang desa. Kekurangan sesaji diharapkan dianggap cukup sehingga dhanyang tidak berbuat ulah, sebaliknya diharapkan dhanyang tidak mengganggu bahkan membatu pelaksanaan pentas.

Pelaksanaan Upacara Adat Bersih Desa

\section{Tahap Pertama}

Upacara adat bersih desa diawali dengan kerja bakti yang dilaksanakan satu Minggu menjelang hari upacara. Kerja bakti merupakan salah satu kegiatan yang sifatnya gotong royong dan diikuti oleh seluruh warga masyarakat tanpa kecuali karena merupakan kepentingan bersama. Lingkungan yang dibersihkan meliputi jalan desa, jalan desa menuju sumber sendang, pundhen dan makam leluhur.

\section{Tahap Kedua}

Bagian kedua merupakan tahap pokok pelaksanaan upacara adat bersih desa. Budiono Herusatoto berpendapat tentang upacara sebagai berikut: Upacara dapat bersifat harian, musiman kadangkala terdiri dari berbagai unsur upacara seperti misal berdoa, bersujud, bersaji, berprosesi, makan bersama, menari dan menyanyi (Budiono Herusatoto, 1934:27-28). 
Upacara adat diawali dengan dibunyikannya kentongan, sebagai tanda bahwa prosesi upacara adat bersih desa akan segera dimulai. Warga masyarakat Desa Bandungrejo mulai berdatangan di rumah Kepala Dusun Taryono, tempat upacara selamatan dilaksanakan. Setelah semua warga masyarakat berkumpul, upacara dimulai. Doa-doa dan mantra diucapkan oleh sesepuh desa.

Doa-doa intinya berisi tentang permohonan doa restu perlindungan kepada para dhanyang/arwah leluhur agar semua warga masyarakat Bandungrejo selalu mendapatkan keselamatan dan terhindar dari segala marabahaya. Setelah selesai membacakan doa-doa, kemudian perlengkapan sesaji selamatan Bandungrejo dimakan bersama-sama oleh semua warga yang hadir.

\section{Bagian Ketiga}

Tahap ketiga merupakan inti dalam rangkaian kegiatan upacara adat bersih desa yaitu pesta berupa pertunjukan Tari Topeng Ireng. Pentunjukan dalam upacara dilaksanakan setelah selamatan upacara adat bersih desa, bertujuan untuk menghadirkan kekuatankekuatan leluhur yang diundang. Melalui doa ataupun mantra yang dibacakan oleh sesepuh yang merupakan pemimpin dalam pentas seni berlangsung.

Apabila diamati penyajian Tari Topeng Ireng dalam upacara adat terbagi menjadi tiga bagian yaitu bagian pra pentas atau awal, pentas atau tengah dan akhir atau penutup. Lebih jelasnya dari pementasan Tari Topeng Ireng dalam upacara adat diuraikan sebagai berikut.

\section{b. Bagian Pra Pentas}

Upacara diawali dengan pembacaan mantra yang dipimpin oleh sesepuh, pada saat pembacaan do'a selalu disertai pembakaran kemenyan dan disertai atau dilengkapi dengan sesaji yang diperuntukan bagi arwah leluhur. Dengan melalui persembahan sesaji yang telah ditempatkan di atas meja secara khusus serta pembacaan mantra atau do'a masyarakat dapat mengadakan komunikasi dengan arwah dari orang yang telah meninggal. Beberapa sesaji yang digunakan dalam pentas pertunjukan Tari Topeng Ireng, yaitu seperti berikut: jenang abang putih, tumpeng cilik, endok dadar, endok Jawa, sego golong, pisang raja, rokok jeruk kretek, tukon pasar, kembang telon dan kenango, godong dadap serep, bumbu cemplung bawang merah/lombok abang, jadah bakar, tempe bakar, wedang teh, kopi, jahe, dan kemenyan madu+lilin (Taryono, wawancara, 8 Nopember 2014).

\section{c. Bagian Pentas}

Pertunjukan Tari Topeng Ireng yang digunakan sebagai pelengkap untuk merayakan upacara adat bersih desa dilakukan dua kali yaitu siang dan malam. Pada waktu siang dimulai setelah jam 16.00 sore. Pada malam hari berlangsung mulai jam 21.00-23.00 WIB.

\section{Tata Urutan Sajian}

Dalam penyajiannya Tari Topeng Ireng dapat dibagi menjadi tiga bagian.

\begin{tabular}{|c|c|c|c|}
\hline No. & Bagian ke-1 & Ragam gerak & Suasana \\
\hline 1. & $\begin{array}{l}\text { Bagian } \\
\text { pertama }\end{array}$ & $\begin{array}{l}\text { penari masuk arena pentas dengan gerakan } \\
\text { onclang dilanjutkan, jalan step melingkar, jalan } \\
\text { mendhak putar ke samping serong, jalan cepat, } \\
\text { langkah step, langkah ayun kaki membalik, } \\
\text { goyang kanan kaki mendhak miring, lenggang } \\
\text { tangan kanan kiri jengkeng, lenggang miring, } \\
\text { laku telu bolak-balik, dan langkah bolak-balik ke } \\
\text { samping jeblos. }\end{array}$ & tintrim, gemuruh,riang, \\
\hline 2. & Bagian ke dua & $\begin{array}{l}\text { Setelah posisi jengkeng para penari bergerak } \\
\text { dengan menggunakan sekaran } \\
\text { a. Jalan mendhak putar ke samping serong, } \\
\text { Jalan cepat; } \\
\text { b. Sekaran Langkah step, langkah ayun kaki } \\
\text { mbalik; sekaran; } \\
\text { c. Ayyn kanan kaki mendhak miring, } \\
\text { Lenggang tangan kanan kiri jengkeng; } \\
\text { sekaran; } \\
\text { d. Lenggang miring, kemudian berhadapan; } \\
\text { e. Sekaran laku telu bolak-balik, Langkah } \\
\text { bolak-balik kesamping jeblos; } \\
\text { f. Sekaran Pola gerak pencak silat diselingi } \\
\text { gerak atraktif yaitu salah satu penari } \\
\text { diangkat dan berdiri dipundak dua orang } \\
\text { penari, penari yang lain gerak salto dan } \\
\text { jengkeng. }\end{array}$ & $\begin{array}{l}\text { riang, gagah, sereng, } \\
\text { enerjik, kuat, yang } \\
\text { didominasi oleh gerak } \\
\text { kaki, dan diselingi } \\
\text { dengan gerak-gerak } \\
\text { atraktif, }\end{array}$ \\
\hline 3. & Bagian ke tiga & $\begin{array}{l}\text { Para penari menggunakan sekaran langkah } \\
\text { sepak kanan kiri tangan lembehan kanan-kiri, } \\
\text { atraktif semua penari membentuk posisi empat } \\
\text { berpasangan dua penari berdiri di atas pundak, } \\
\text { kemudian seorang penari di atas dua kelompok } \\
\text { pasangan berdiri standent diteruskan turun } \\
\text { bergerak membentuk formasi dua kelompok } \\
\text { menghadap ke depan sambil memberikan } \\
\text { horamat dengan berjalan di tempat tanagn } \\
\text { kanan diayunkan ke atas sambal membungkuk } \\
\text { dilanjutkan berjalan urut kacang sambil menari } \\
\text { masuk meninggalkan arena pentas, dengan } \\
\text { gerakan onclang ke luar. }\end{array}$ & $\begin{array}{l}\text { gemuruh, riang, } \\
\text { gembira }\end{array}$ \\
\hline
\end{tabular}

\section{Fungsi Tari Topeng Ireng Dalam Upacara Bersih Desa}

Berdasarkan pengamatan pertunjukan Tari Topeng Ireng pada upacara adat bersih desa memiliki beberapa fungsi di antaranya

\section{a. Fungsi Estetis}

Dalam sajian Tari Topeng Ireng sebagai sarana bersih desa, memiliki nilai estetis melalui penampilan gerak dan iringan. Alunan iringan yang berirama keras menunjukan semangat para pengrawit dan ditunjang dengan gerak tari yang rampak sehingga penari merasakan gerak yang mantap. Penonton yang hadir dan melihat tanpa disadari mereka menikmatinya dengan menggeleng-gelengkan kepala, kadangkadang dengan menggerakan tangannya. Pendapat Kant dalam Dick Hartoko menyatakan bahwa pengalaman estetik itu bersifat "sepi ing pamrih" (Dick Hartoko, 1984:12). Terdapat sambung rasa antara dalam bentuk karya seni dengan penghayatannya. 


\section{GEEAR Jumal sai isulyaa}

Pertunjukan Tari Topeng Ireng dapat memberikan pengalaman estetis, memperkaya pengalaman jiwa, dan memperluas persepsi karena dengan melihat, merasakan dan menikmati bentuk sajian secara utuh maka dapat meningkatkan daya apresiasi seni, yang pada gilirannya akan memperkaya pengalaman jiwa.

\section{b. Fungsi Hiburan}

Tari Topeng Ireng dipentaskan selain sebagai rangkaian upacara bersih desa dalam acara inti juga berfungsi sebagai hiburan yaitu baik bagi penari maupun warga masyarakat yang hadir. Tari Topeng Ireng sebagai sarana upacara adat bersih desa juga sebagai hiburan bagi diri penari karena dianggap sebagai pelepas kejenuhan dari kegiatannya seharihari. Warga masyarakat biasanya melakukan kegiatan yang dapat mengungkapkan perasaan dan pikiran secara bebas. Kegiatan kesenian merupakan salah satu sarana yang dapat diikuti oleh banyak orang tanpa menimbulkan rasa perlawanan, karena disajikan secara indah sehingga dapat memberikan kenikmatan dan kepuasan jiwa. Sebagai hiburan karya seni dapat melepaskan ketegangan jiwa sehingga menjadi terapi kejiwaan (Budhi Santoso, 1994; dalam Suharji, 2017:2).

Pementasan Topeng Ireng merupakan hiburan bagi masyarakat atau penonton yang hadir, baik yang berasal dari Bandungrejo maupun desa lainya. Masyarakat berbondong-bondong datang ke Bandungrejo untuk menyaksikan secara langsung pertunjukan Tari Topeng Ireng yang dipentaskan. Pertunjukan tari dapat memberi hiburan yang segar bagi masyarakat di samping dapat merasakan kegembiraan dalam suasana pertunjukan. Tari Topeng Ireng sebagai hiburan karena menyegarkan batin dan menambah khasanah budaya.

\section{c. Fungsi Simbolis atau Perlambang}

Upacara adat bersih desa Bandungrejo merupakan kegiatan ritual untuk menghormati para leluhurnya. Melalui upacara ritual yang didukung oleh Tari Topeng Ireng merupakan perlambang bagi masyarakat Bandungrejo masih memegang teguh adat kebiasaan, naluri terhadap tradisi yang diwarisi secara turun menurun dari leluhurnya.

Hasil karya seni merupakan simbolisme untuk mencapai maksud tertentu. Melalui simbol-simbol seni seniman mengungkapkan dan menyatakan perasaan dan pemikiran secara terselubung. Dengan karya seni seseorang dapat mempengaruhi kekuatan gaib untuk memberikan bantuannya. Beberapa karya seni yang memenuhi standard of excellent mampu membangkitkan perasaan suka, benci, marah, sedih, sesuai dengan pesan-pesan terselubung yang disampaikan melalui karya-karya seni. (Budhi Santoso, 1994; dalam Suharji, 2017:7).

Tari Topeng Ireng sebagai simbol tari persembahan yang dihaturkan kepada dhanyang leluhur yang menguasai wilayah desa dan Dewi Sri yang telah memberikan kelimpahan panen. Masyarakat Bandungrejo percaya bahwa pertunjukan Tari Topeng Ireng dalam upacara adat bersih desa mengandung kekuatan magis, sehingga dapat dipergunakan sebagai sarana untuk mencapai keselamatan.

Upacara adat bersih desa dengan pertunjukan Tari Topeng Ireng merupakan lambang dari komunikasi dua arah yaitu secara vertikal memberi penghormatan atau ucapan terima kasih terhadap Tuhan, serta dhanyang pelindung dukuh bahwa diberi panen yang melimpah sebagai lambang kesuburan. Secara horizontal yaitu terhadap sesama seperti memelihara kerukunan memperkuat gotong royong atau kebersamaan masyarakat dalam membina dukuhnya.

\section{d. Fungsi Pengesahan Lembaga Sosial dan Ritus Kehidupan}

Tari Topeng Ireng yang mengiringi upacara bersih desa merupakan salah satu tradisi atau adat istiadat dalam kehidupan yang berlaku guna memenuhi kebutuhan akan keselamatan dan ketentraman bagi masyarakat Bandungrejo. Adat istiadat desa sudah menjadi aturan yang melekat pada jiwa masyarakat untuk keperluan berhubungan dengan Tuhan maupun alam gaib sehingga kebutuhan masyarakat dapat terpenuhi. Pada upacara adat bersih desa dan pementasan Topeng Ireng diadakan doa dan sesaji agar tidak ada gangguan apapun baik menyangkut penari serta warga masyarakat Bandungrejo.

Wujud karya seni sebagai pernyataan dan penjilmaan pemikiran seniman, dapat merangsang kepekaan empati masyarakat. Karya seni yang bermutu menimbulkan tanggapan emosional yang dapat menumbuhkan rasa kebersamaan yang menyangkut di antara pengagumnya. Seni merupakan sarana pengesahan lembaga sosial masyarakat (Budhi Santoso, 1994; dalam Suharji, 2017:4).

Masyarakat patuh pada aturan dan adat tradisi yang berlaku maka upacara adat bersih desa secara rutin selalu dilaksanakan setiap tahun. Bagi masyarakat Bandungrejo terdapat tabu untuk melanggar, takut akan terjadi musibah yang tidak diinginkan. Masyarakat Bandungrejo yang mayoritas 
beragama Islam, memiliki toleransi yang tinggi terhadap kepercayaan lama sehingga tidak mempengaruhi ketaatannya dalam beribadah tetapi merupakan kewajiban yang dijalankan bersama.

\section{e. Fungsi Pengintegrasian Masyarakat}

Pertunjukan Tari Topeng Ireng dalam upacara adat bersih desa merupakan wujud kerukunan hidup masyarakat Bandungrejo. Upacara adat bersih desa dengan pertunjukan Tari Topeng Ireng menumbuhkan kesadaran untuk saling mengenal, menghormati, menghayati, serta menumbuhkan identitas sebagai ikon desa. Pertemuan yang tidak disengaja dengan adanya pementasan Tari Topeng Ireng dapat saling bertemu, berkenalan, serta menjalin keakraban. Dalam kegiatan bersih desa tercermin sikap gotong royong, saling membantu yang diungkapkan melalui kerja bakti, penataan persiapan upacara dan sebagainya. Melalui gotong-royong seluruh warga masyarakat dengan tidak memandang derajat, sehingga dapat menumbuhkan semangat persatuan di antara warga masyarakat. Radcliffe Brown yang dikutip oleh Ihromi menyatakan bahwa aspek perilaku sosial bukanlah berkembang untuk memuaskan kebutuhan individual tetapi justru timbul untuk mempertahankan struktur sosial masyarakat (Ihromi, 1986:61). Dengan pertunjukan Topeng Ireng dalam upacara adat bersih desa dapat menjadikan kerukunan hidup masyarakat menjadikan kesatuan, kebersamaan, kerukunan, kebahagiaan dan harmoni masyarakat.

\section{f. Fungsi Ritual}

Fungsi ritual berhubungan dengan kesuburan. Ritus kehidupan manusia bagi kehidupan masyarakat adalah tercapainya kebahagiaan. Bagi petani ritus kesuburan berhubungan dengan pertanian, karena masyarakat Bandungrejo dalam kehidupan sehariharinya mayoritas sebagai petani. Dalam pertanian kesuburan tanah, panen melimpah, dijauhkan dari marabahaya menjadi salah satu tujuan dalam setiap peristiwa ritual. Melalui upacara adat ritual yang berlangsung secara khidmat diharapkan mendatangkan keberhasilan dalam hidup. Masyarakat Bandungrejo selalu melaksanakan upacara adat ritual dengan disertai pertunjukan seni yang telah mentradisi. Tradisi yang dimaksud yaitu upacara bersih desa yang biasa diadakan setelah panen. Setiap pelaksanaan upacara adat bersih desa selalu menampilkan Topeng Ireng yang telah menjadi warisan turun temurun.

Edi Sedyawati menjelaskan bahwa melalui upacara yang digunakan untuk kekuatan magis salah satunya bertujuan untuk mendatangkan kesuburan tanah. Selanjutnya masyarakat melakukan upacara sebagai ucapan syukur kepada Tuhan, Nabi, dhanyang dan Dewi Sri atas keberhasilan panen dengan harapan panen yang akan datan bisa melimpah dan tidak terserang hama. Dengan demikian dalam fungsi kesuburan berkaitan dengan lambang kesuburan tanah (1981:65).

\section{g. Fungsi Pendidikan}

Tari Topeng Ireng mengandung fungsi pendidikan dalam arti harus melibatkan proses kreatif dan apresiatif yang dapat memacu kerja sama antara pikiran, perasaan dan tindakan. Pendidikan tari rakyat senantiasa diarahkan kepada aspek kreasi, bisa melalui pengalaman praktis maupun teoritis. Aspek kreasi menyangkut aktivitas kreatif guna menemukan arti dan bentuk baru terhadap nilai-nilai kehidupan (Jazuli,2011:38-39).

Nilai pendidikan sebagai contohnya dapat diketemukan pada gerak-gerak lembut-kasar, aturanaturan tertentu, tema-tema yang digunakan, sikapsikap gerak yang terdapat di dalamnya. Tema kepahlawanan Tari Topeng Ireng terdapat di dalam gerak tari, sering digambarkan gerakan-gerakan yang penuh enerjik baik halus dan kasar. Penanaman nilai pendidikan menumbuhkan sikap percaya diri, disiplin, dan keteguhan jiwa seseorang.

\section{Faktor Pendukung Dan Penghambat Pentas Tari Topeng Ireng Dalam Rangka Upacara Bersih Desa}

\section{Faktor internal}

a. Dalam pertunjukan Tari Topeng Ireng untuk mengiringi upacara adat bersih desa Bandungrejo melibatkan banyak warga masyarakat untuk mengambil bagian dan berperan serta. Sedikitnya 20 orang warga menjadi penari, 8 orang sebagai pengrawit, 2 orang vokalis, 6 pembantu pengrawit. Beberapa orang warga menyiapkan pentas dan mempersiapkan peralatan pertunjukan seperti misalnya mengusung kursi, kajang dari kantor desa menuju tempat pentas, warga yang lain mempersiapkan sesaji, hidangan, dan menurut keperluan lainya. Warga masyarakat akan merasa puas jika dapat ikut serta dalam upacara ritual yang dilengkapi dengan pertunjukan Tari Topeng Ireng. Merupakan kepuasan tersendiri jika beberapa orang warga menjadi pelaku. Para warga masyarakat menjadi terhibur sehingga dapat menambah semangat untuk lebih giat bekerja di 


\section{GEEAR Jumal Sari iuduya}

ladang, setelah melaksanakan ritual bersih desa. Untuk lebih mempertebal keyakinan, pentas seni juga dirangkai dengan kesenian lain seperti contohnya Kuda Lumping, Soreng, dan Srien yang betemakan keprajuritan, dilatih oleh pemimpin paguyuban Wargo Setuju yang menciptakan tarian Topeng Ireng.

b. Pertunjukan Tari Topeng Ireng menyenangkan dan menarik hati, menjadikan daya tarik warga desa lain untuk melihatnya. Pentas Tari Topeng Ireng yang dipilih menyesuaikan dengan selera masyarakat sehingga dapat menampung selera masyarakat dalam mendapatkan hiburan. Dalam seni yang penting paraganya yang senang dan kemudian masyarakat yang menikmatinya juga merasa terhibur, merasa puas. Masyarakat merasa ingin memiliki sehingga pertunjukan akan tetap dilestarikan.

c. Seniman pengrawit, penari masih muda, gagah dan dikenal banyak pengalaman serta memiliki angsarl petuah yang baik. Semua penari dan pengrawit dari desa setempat sehinggga dapat menghemat beaya, menghemat waktu dan tenaga, pertunjukan akan selalu didukung oleh warga setempat oleh karena sebagai kebanggaan. Warga desa memiliki kekayaan budaya yang tidak dimiliki warga yang lain. Meskipun telah banyak hiburan dari kesenian yang lain, oleh karena pertunjukan Tari Topeng Ireng berkaitan dengan acara ritual adat, sehingga banyak warga yang merasa yakin bahwa dengan berkesenian sendiri akan lebih mewakili dirinya untuk berhubungan dengan kekuatan luar yang diharapkan akan mendatangkan ketenteraman, keselamatan dan kebahagiaan.

d. Penonton tidak terbatas pada warga setempat baik laki-laki maupun perempuan dewasa, tua, dan anak-anak. Penonton juga banyak dari warga desa yang lain, sebagian warga lain memang memerlukan untuk ikut ritual dan juga menikmati pementasan tari. Jika memiliki angsar yang baik maka akan dipentaskan setiap tahunya sebagai hiburan yang segar dan sesuai dengan adat desa setempat.

\section{Faktor Eksternal.}

a. Pengaruh Cuaca di lingkungan Bandungrejo.

Masyarakat Bandungrejo merasa lebih mantap jika tradisi bersih desa diselenggarakan pada hari Rabu Kliwon, bulan Sapar pada penanggalan Jawa, kebetulan tahun 2014 jatuh pada musim penghujan, meskipun demikian hampir semua petani telah selesai menanam jagung dan palawija, sebagian besar warga relatif banyak istirahat, banyak waktu luang, sehingga hampir semua warga masyarakat melestarikan tradisi silaturahim.

Pada upacara adat selalu diselenggarakan pertunjukan tari hasil karya kreatifitas warganya sendiri. Warga puas jika dapat berpartisipasi dalam rangka upacara ritual oleh karena merasa memiliki sumbangan yang berharga bagi kepentingan desanya. Akan tetapi oleh karena selalu mengikuti arus musim yang kadang-kadang jatuh pada musim penghujan sehingga mengganggu jalannya upacara ritual, untuk itu upacara ritual dilakukan pada siang hari setelah Ashar hingga sore hari. Jika belum puas dilanjutkan pada malam harinya, sedang tempat telah dipilih di halaman yang luas milik warga. Cara yang ditempuh merupakan kebijaksanaan yang tepat oleh karena terpengaruh cuaca, sehingga perubahan waktu upacara merupakan pilihan yang relatif baik. Pengaruh cuaca pada lereng pegunungan sangat cepat berubah sehingga memerlukan perhitungan yang tepat.

\section{b. Pengaruh dari dinas pariwisata.}

Setelah debut Tari Topeng Ireng mendapatkan kesan yang baik, banyak warga masyarakat yang lain menyaksikan dan ikut menjadi penari (Taryono, wawancara 8 Nopember 2014). Beberapa tokoh masyarakat saling merasa kagum karena dengan pertunjukan Topeng Ireng dapat mempersatukan warga masyarakat disamping melestarikan kesenian rakyat. Anggauta kelompok menjadi semakin banyak dan giat bersemangat dalam menari. Sekalipun bentuknya relatif sederhana, bagi masyarakat merupakan salah satu syarat untuk kegiatan ritual sehingga pertunjukan Tari Topeng Ireng tetap dipertahankan. Beberapa pejabat dinas pariwisata merasa terpanggil untuk mengangkat Upacara adat ritual sebagai salah satu daya tarik obyek wisata yang berupa peninggalan budaya dengan ujud atraksi seni. Untuk menunjang kehadiran wisata, maka diperlukan prasarana yang memadahi dan juga pembenaan obyek wisata. Sebagaimana diketahui bahwa untuk mengundang wisatawan diperlukan penanganan yang seksama. Obyek wisata yang menarik meliputi keindahan alam seperti misalnya adat dan kegiatan ritual masyarakat, gugusan pegunungan dengan udara yang indah ditunjang dengan peninggalan kebudayaan. Dalam hal kebudayaan diperlukan pengurusan tentang peninggalan budaya ataupun atraksi budaya.

c. Pengaruh dari perkembangan hasil tekhnologi.

Bandungrejo telah banyak dimiliki pesawat televisi yang dapat menangkap siaran langsung baik berupa berita maupun hiburan. Kehadiran hiburan yang 
ditayangkan televisi menambah apresiasi masyarakat, namun demikian jangkauan harta kekayaan masyarakat tidak sanggup untuk mengundang hiburan yang ditayangkan oleh televisi. Dalam upacara adat ritual masyarakat lebih percaya dengan kekuatan dan kemampuan sendiri untuk berhubungan dengan kekuatan gaib. Pertunjukan Tari Topeng Ireng untuk upacara adat bersih desa pada jaman sekarang justru diminati oleh banyak warga masyarakat apalagi penari, paraga dan kelengkapannya dari masyarakat sendiri. Hiburan untuk kegiatan ritual selalu berkaitan dengan norma etika yang dianut masyarakat. Adat sopan santun, kesederhanaan, ketulusan dan kerukunan menjadikan pedoman untuk selalu menjaga kelestarian alam dan manusia sehingga akan mendatangkan kebahagiaan. Banyak hiburan yang menarik secara umum, akan tetapi untuk kegiatan ritual masih banyak yang lebih percaya pada pertunjukan rakyat yang dapat digunakan untuk menyampaikan pesan tentang harapan dan keinginan warga setempat. Peran perangkat desa untuk melindungi kebudayaan sendiri merupakan kewajiban luhur oleh karena jika kebudayaan yang aseli ditinggalkan justeru akan menimbulkan kesusahan masyarakat. Dengan kebudayaan sendiri akan menumbuhkan cinta tanah air dan bangsa. Dalam pertunjukan Tari Topeng Ireng yang menggunakan bantuan sarana hasil tekhnologi, akan tetapi penghayatan rohani yang harus dialami sendiri merupakan faktor penting bagi kelangsungan upacara adat desa setempat.

\section{Kesimpulan}

Upacara adat bersih desa Bandungrejo dengan pertunjukan Tari Topeng Ireng memiliki banyak fungsi. Dipercaya masyarakat, dengan pertunjukan Tari Topeng Ireng akan mendatangkan angsar yang baik, menghibur, perlambang, pengesahan lembaga sosial dan ritus kehidupan, pengintegrasian masyarakat, ritual, dan pendidikan.

Pertunjukan Tari Topeng Ireng akan mendatangkan kebahagiaan bagi semua warga masyarakat. Pertunjukan memiliki makna pokok yaitu sebagai rasa syukur dan memohon kepada Tuhan yang Maha Esa agar seluruh warga desa mendapatkan berkah, dijauhkan dari berbagai gangguan, terkabul semua keinginan warga desa. Pertunjukan Tari Topeng Ireng merupakan sarana upacara adat selalu diminati oleh warga masyarakat sehingga setiap tahun selalu dilaksanakan.

\section{KEPUSTAKAAN}

Budiono Herusatoto. Simbolisme dalam Budaya Jawa. Yogyakarta: Hanindita, 1983.

Dick Hartoko, ed. Memanusiakan Manusia Muda. Yogyakarta: Yayasan Kanisius. 1985.

Edi Sedyawati, Pertumbuhan Seni Pertunjukan. Jakarta: Sinar Harapan, 1981.

Tari Tinjauan dari Berbagai Segi. Jakarta: Pustaka Jaya, 1984.

Heddy Shri Ahimsaputra. "Wacana Seni dalam Antropologi Budaya: Tekstual, Kontekstual dan Post modernistis", dalam Heddy Shri Ahimsa Putra (ed); Ketika Orang Jawa Nyeni. Yogyakarta: Galang Press, 2000.

Hadi Sumandya Y. Kajian Tari teks dan konteks Yogyakarta: Pustaka Book Publiser, 2007.

Sosiologi Tari. Yogyakarta: ISI Press, 2006.

Jazuli M., Sosiologi Seni, Surakarta: UNS Press, 2011.

- Pendidikan Seni Budaya Suplemen Pembelajaran Seni. Semarang: Universitas Negeri Semarang Press, 2008

Maleong, Lexy. J. Metode Penelitian Kualitatif. Bandung: PT Remaja Rosdakarya, 2007.

Nyoman Kutha Ratna, Metode Penelitian Kajian Budayadan Ilmu Sosial Humaniora Pada Umumnya. Yogyakarta: Pustaka Pelajar, 2010.

Soemaryatmi, "Pengembangan Kreativitas Kesenian Rakyat Sebagai Pelestarian Budaya dan Upaya Pembentukan Karakter Generasi Muda di Kecamatan Selo" Laporan Penelitian Hibah Bersaing. Surakarta: Institut Seni Indonesia (ISI), 2011.

"Dampak Akulturasi Budaya Pada Kesenian rakyat Kecamatan Selo Boyolali" 2012. Bandung: Panggung Jurnal Seni \& Budaya Vol 22. No. 1. Januari-Maret 2012. 


\section{GELAR Jumal saib butsya}

"Kreatif Inovatif Tari Topeng Ireng" Proseding Pengabdian Kepada Masyarakat. Surakarta: LPPMPP Institut Seni Indonesia (ISI) , 2012.

Suharji, "Transformasi Seni Tradisi di Era Globalisasi” Proseding Seminar Nasional 15 Oktober 2012. Paradigma Perguruan Tinggi Seni Sebagai Kesadaran Kolektif Menghadapi Globalisasi, 2012.

,Sosiologi Seni Pengantar Secara Sistematik. Surakarta: ISI Press. Buku Ajar, 2017.
,Pengembangan Kreativitas Kesenian Rakyat Sebagai Pelestarian Budaya dan Upaya Peningkatan Industri Kreatif Di Desa Bandungrejo, Kecamatan Ngablak, Kabupaten Magelang. Laporan Penelitian Hibah Bersaing. Surakarta: Institut Seni Indonesia (ISI), 2013

Sutopo, Hb., Metode Penelitian Kualitatif. Surakarta: UNS Press, 2006. 